\title{
PREVALENCE AND PROFILE OF ALOPECIA AREATA IN MANIPUR: A RETROSPECTIVE ANALYTICAL STUDY
}

\author{
Yumnam Lokendra Singh ${ }^{1}$, Keisham Chitralekha², Leishangthem Nabina ${ }^{3}$, Heisnam Kulabidhu Singh ${ }^{4}$ \\ ${ }^{1}$ Assistant Professor, Department of Dermatology, JN Institute of Medical Sciences, Imphal. \\ ${ }^{2}$ Senior Resident, Department of Dermatology, JN Institute of Medical Sciences, Imphal. \\ $3 J u n i o r$ Resident, Department of Dermatology, JN Institute of Medical Sciences, Imphal. \\ ${ }_{4}^{4}$ Associate Professor, Department of Community Medicine, JN Institute of Medical Sciences, Imphal.
}

\begin{abstract}
Alopecia areata is a non-scarring auto-immune hair loss on the scalp and/or body. Both males and females are equally affected. The disease can occur at any age. Data regarding the magnitude and profile of this disease is almost non-existent for the NorthEastern part of the country.

\section{OBJECTIVE}

The current study was taken up to make an estimate of the prevalence of alopecia areata in the state of Manipur and also to explore the profile of the patients.

\section{MATERIALS AND METHODS}

Data maintained in the OPD, Department of Dermatology, Manipur for the last 10 years (2006-2015) were retrospectively analysed for new cases of alopecia areata.

\section{RESULTS}

The prevalence of alopecia areata out of all the patients who attended the OPD was $2.17 \%$. The mean age (SD) of the patients was $24.45( \pm 13.74)$ years. Children below 14 years constituted $21 \%$ of all the cases. Majority of the patients (46\%) belonged to the agegroup of 15-30 years. On the average, there was male preponderance (M:F = 1.43:1). In the age group of 15-30 years, this ratio went up to $2.08: 1$. More than two-thirds of the patients (68.2\%) were from the rural areas of the state.
\end{abstract}

\section{CONCLUSION AND RECOMMENDATION}

The prevalence of alopecia areata in the state of Manipur was found to be $2.17 \%$ of all the OPD cases in the Department of Dermatology. There was male preponderance for the cases. A community-based study is recommended so that an accurate community-based prevalence maybe estimated.

\section{KEYWORDS}

Alopecia Areata, North-Eastern India, Prevalence, Profile.

HOW TO CITE THIS ARTICLE: Singh YL, Chitralekha K, Nabina L, et al. Prevalence and profile of alopecia areata in Manipur: a retrospective analytical study. J. Evolution Med. Dent. Sci. 2016;5(61):4251-4253, DOI: 10.14260/jemds/2016/970

\section{INTRODUCTION}

Alopecia areata is a non-scarring autoimmune hair loss on the scalp and/or body. Aetiology and pathogenesis are still not clearly known. The most common site affected is the scalp in the form of solitary or multiple patches of alopecia. The disease was first described by Cornelius Celsus and the term alopecia areata was first coined by Sauvages in $1760 .{ }^{1}$ Both males and females are equally affected,2,3 yet some other studies reported the ratio to be higher among males. ${ }^{4-8}$ The disease can occur at any age including infancy period. ${ }^{9} 20-25 \%$ of cases are seen among children ${ }^{1}$, the prevalence being highest during 30-59 years of age.1,2,3,7,8 Some other researchers reported a lower age of onset.10,11 The prevalence of the disease in different parts of the world varies from 0.7 to $3 \% \cdot 1,2,4$

Financial or Other, Competing Interest: None.

Submission 18-06-2016, Peer Review 20-07-2016,

Acceptance 25-07-2016, Published 29-07-2016.

Corresponding Author:

Dr. Heisnam Kulabidhu Singh,

Department of Community Medicine,

JNIMS, Imphal-795005,

Manipur.

E-mail: kb_heisnam@rediffmail.com

DOI: $10.14260 /$ jemds/2016/970
Data on the magnitude and profile of alopecia areata patients are rarely available for the North-Eastern part of India. Hence, the current study was taken up.

\section{OBJECTIVE}

To make an estimate of the prevalence of alopecia areata and to explore the profile of the patients.

\section{MATERIALS AND METHODS}

The study was a retrospective, hospital-based study. Patients attending the Outpatient Department (OPD) of the Department of Dermatology of the State Medical College (JN Institute of Medical Sciences, Manipur) during the last 10 years (2006-2015) were the study subjects. Secondary data maintained at the OPD of the same department was the source of information. Only those patients who were diagnosed for alopecia areata for the first time in his/her life were included for analysis implying that patients on followup visits were excluded. No identifiers like names were used for data analysis. Descriptive statistics like percentages, mean, median, and standard deviation were used for data analysis. 


\section{RESULTS}

During the period 2006-2015, a total of 227, 238 patients attended the OPD of the Department of Dermatology, JNIMS out of which 494 cases were cases of alopecia areata $(2.17 \%)$ The annual prevalence for the last 10 years was found to be $3.15 \%$ (2006), 2.05\% (2007), 2.18\% (2008), 1.54\% (2009), $2.65 \%$ (2010), 3.05\% (2011), 1.66\% (2012), 2.49\% (2013), $1.92 \%$ (2014), and $2.11 \%$ (2015).

The mean age (SD) and median age of the alopecia areata patients were 24.45 years $( \pm 13.74)$ and 24 years respectively. The youngest patient was a child aged 14 days whereas the oldest one was 67 years old. The number of children ( $<14 \mathrm{yrs}$.) cases out of the total 494 cases was 103 (20.9\%). The age distribution of all the cases of alopecia areata was as given below in Table 1.

\begin{tabular}{|c|c|}
\hline Age-Groups (in yrs.) & Number of Patients (\%) \\
\hline$<15$ & $128(25.9)$ \\
\hline $15-<30$ & $228(46.2)$ \\
\hline $30-<45$ & $101(20.4)$ \\
\hline $45-<60$ & $31(6.3)$ \\
\hline 60 and above & $6(1.2)$ \\
\hline \multicolumn{2}{|c|}{ Table 1: Age Distribution of Alopecia Areata } \\
Patients (n = 494)
\end{tabular}

Majority of the alopecia areata patients were aged 15-30 years (46\%) followed by subjects aged $<15$ yrs. (26\%) and people aged 30-40 yrs. (20\%). It was rarely seen among older people aged 60 years or more $(1 \%)$.

The total number of male cases out of the total 494 cases was 291 giving a male:female ratio of 1.43:1. There was slight variation in this ratio across the different years of study (Table 2). In the years 2009 and 2012, female patients outnumbered male patients.

\begin{tabular}{|c|c|c|c|}
\hline Years & Males & Females & M:F Ratio \\
\hline 2006 & 22 & 19 & $1.16: 1$ \\
\hline 2007 & 29 & 15 & $1.93: 1$ \\
\hline 2008 & 27 & 17 & $1.59: 1$ \\
\hline 2009 & 21 & 22 & $0.95: 1$ \\
\hline 2010 & 25 & 23 & $1.09: 1$ \\
\hline 2011 & 35 & 22 & $1.59: 1$ \\
\hline 2012 & 22 & 23 & $0.96: 1$ \\
\hline 2013 & 35 & 20 & $1.75: 1$ \\
\hline 2014 & 40 & 21 & $1.90: 1$ \\
\hline 2015 & 35 & 21 & $1.67: 1$ \\
\hline Total & 291 & 203 & $1.43: 1$ \\
\hline Table 2: Year-Wise Sex Composition of Alopecia Areata \\
\multicolumn{4}{|c}{ Patients } \\
\hline
\end{tabular}

The male:female ratio of the cases of alopecia areata across the different age group showed that males suffered from the disease doubly more than the females in the age group of 15$<30$ years. For the other age groups, there was only slight male preponderance except for the age group of 60 or more years (Table 3).

\begin{tabular}{|c|c|c|c|}
\hline $\begin{array}{c}\text { Age-Groups } \\
\text { (in yrs.) }\end{array}$ & Male & Female & M:F Ratio \\
\hline$<15$ & 67 & 61 & $1.10: 1$ \\
\hline $15-<30$ & 154 & 74 & $2.08: 1$ \\
\hline $30-<45$ & 53 & 48 & $1.10: 1$ \\
\hline $45-<60$ & 16 & 15 & $1.07: 1$ \\
\hline 60 and above & 1 & 5 & $0.17: 1$ \\
\hline \multicolumn{3}{|c|}{ Table 3: Alopecia Areata Patients by } \\
Sex and Age (n= 494) \\
\hline
\end{tabular}

More than two-thirds of the patients (337, 68.2\%) belonged to the rural part of the country. This proportion showed a slightly rising trend during the years 2011 (79\%), 2013 (76\%), and 2015 (73\%).

\section{DISCUSSION}

The prevalence rate of $2.17 \%$ for alopecia areata as found out from the current study was on the higher side when compared to results reported by Sharma VK et al $^{1}$ from their study done in the northern India. Yet, it was comparable with other findings reported by Tan E et al from their study at Singapore ${ }^{2}$ and by Safavi $\mathrm{KH}$ et al ${ }^{4}$ in United States of America. From the current study, $21 \%$ of the alopecia areata patients were found to be children aged less than 14 years. This also was found comparable with the findings made by Sharma VK et al in northern India. The youngest case seen from the current study was only 14 days old, which is much younger than reported by Muller SA et al7.

The male:female ratio of $1.43: 1$ of the alopecia areata patients was in accordance with earlier study finding made by Tan $\mathrm{E}$ et $\mathrm{al}^{2}$, Safavi $\mathrm{KH}$ et $\mathrm{al}^{4} \mathrm{Al}-\mathrm{Mutani} \mathrm{N}$ et $\mathrm{al}^{5}$ and Bhat $\mathrm{YJ}$ et al 6 The low male:female ratio among patients aged 60 years or more might be because of the fact that females in this agegroup took the disease more seriously compared to male patients. The later finding could not be compared with other study findings as no other study has reported on this aspect.

More than two-thirds of the alopecia areata patients in the current study belonged to rural areas of the state. This finding was in support of the reports made by Sehgal BN et al 12 that socioeconomic factors might play a role in the initiation, development, and persistence of alopecia areata.

\section{CONCLUSION AND RECOMMENDATION}

The estimated prevalence rate of alopecia areata among all patients who attended the outpatient department of the Department of Dermatology in JNIMS, the state medical college of Manipur in the last ten years was found to be $2.17 \%$. There was male preponderance for the cases. All age groups were affected. The highest being among adults aged 15-30 years. Even infants suffered from the disease. Patients from the rural areas outnumbered patients from the urban areas of the state.

A community-based study might be taken up in future, so that an accurate community-based prevalence of the disease may be made.

\section{ACKNOWLEDGEMENT}

The authors acknowledge the valuable inputs from the various researchers from whom references are quoted. 


\section{REFERENCES}

1. Sharma VK, Dawn G, Kumar B. Profile of alopecia areata in northern India. Arch Dermatol 1992;128(5):702.

2. Tan E, Tay YK, Giam CY, et al. The pattern and profile of alopecia areata in Singapore - a study of 219 Asians. Int J Dermatol 2002;41(11):748-53.

3. Frickle VAC, Miterva M. Epidemiology and burden of alopecia areata: a systematic review. Clin Cosmet Investig Dermatol 2015;8:397-403.

4. Safavi KH, Muller SA, Suman VJ, et al. Incidence of alopecia areata in Olmsted County, Minnesota, 1975 through 1989. Mayo Clin Proc 1995;70(7):628-33.

5. Al-Mutani N, Eldin ON. Clinical profile and impact on quality of life: seven years' experience with patients of alopecia areata. Ind J Dermatol Venerol Leprol 2011;77(4):489-93.

6. Bhat YJ, Manzoor S, Khan AR, et al. Trace element levels in alopecia areata. Ind $\mathrm{J}$ Dermatol Venerol Leprol 2009;75(1):29-31.
7. Muller SA, Winkelmann RK. Alopecia areata - an evaluation of 736 patients. Arch Dermatol 1993;88: 290-7.

8. Ranawake RR. An observational study of alopecia areata in Sri Lankan adult patients. Ceylon Med J 2014;59(4):128-31.

9. McMichael AJ, Pearce DJ, Wasserman D, et al. Alopecia in the United States: outpatient utilisation and common prescribing patterns. J Am Acad Dermatol 2007;57(2Suppl):S49-51.

10. Amer E, Khallid J, Majid S, et al. Pattern and profile of alopecia areata in Pakistan. J. of Pakistan Assoc of Dermatol 2009;19:136-40.

11. Hassan S, Maryam A, Hamid A, et al. Evaluation of the profile of alopecia areata and prevalence of thyroid function test abnormalities and serum autoantibodies in Iranian patients. BMC Dermatol 2005;5:11.

12. Sehgal VN, Srivastava G, Aggarawal A, et al. Alopecia areata in the Indian subcontinent. Skinmed 2007;6(2): 63-9. 